\title{
PRAIRIE LORE AND LIVING SOCIETY, SASKATCHEWAN
}

\author{
by NORA M. STEWART*
}

An organization to promote the nowledge and appreciation of the prairie outdoors, an understanding of man's impact on the environment hrough agricultural and other pracices, and the achievement of a balance between conservation of wildlife and ts habitat on the one hand and the nevitable use of the land by man on he other - these are the basic goals of he non-profit Prairie Lore and Living fociety. Because I feel these aims are hared with most naturalists, I would ike to explain our organization riefly, and suggest ways in which our ommon objectives may be achieved.

We feel that the most effective way o increase awareness of these values is hrough education, and have chosen to vork in conjunction with the schools. Dur group is developing an outdoor ducation center to which classes from ny school (likely grades 5-12) will be ble to come on a weekly basis to experience the outdoors in some of many ossible pursuits. This will entail imple winterized accommodations, onsiderable equipment, a small esource staff to assist the teachers and in associated ranch-farm.

It is getting increasingly difficult for chool boards to find mixed farms hich classes can visit and this one vould have a wide variety of livestock nd crops. It would be set up to allow asy observation and involvement of he students, where possible. An atcmpt will be made to combine the cologically safest modern farming echniques with a variety of older

Craven, Sask. methods including horse-drawn equipment and windmills.

It is difficult to appreciate the outdoors without getting out, and the mastering of various outdoor skills for all seasons will be encouraged in the hope that lifelong interests will develop. Whether by canoe, crosscountry skis, snowshoes, horseback or on foot, travelling outdoors likely will result in a joy of effort and a greater awareness of the beauty and complexity of nature on the prairies. Lest anyone feel that these are frivolous pastimes for students who should be at their books, consider just a few examples of things which may be learned best outdoors: for math, survey a fence line: for history, re-enact an important historical event with costumes; or, visit an oil field, sketch a gnarled tree, measure the oxygen content of a pond, identify an animal track. The list is endless.

The proposed center should have access to a variety of habitat and the land we have chosen, for what may be only the first such center, lies on the south slopes of the Moose Mountains. It runs south for 1-1/2 miles from the aspen forest of Moose Mountain Provincial Park through slough-dotted brushland to native prairie, with 60 acres cultivated and has a commanding view of the flat prairie lands beyond. It is hard to imagine an area with richer geographical variety and potential for our endeavour. The park itself provides a wilderness for adventure-filled trips which might include sightings of deer, moose or elk. The identification of local birds and plants 
is a challenge. History is there, with early homesteads, the Indian tipi rings and medicine wheel, and nearby Cannington Manor.

We feel that this opportunity to integrate learning with the living laboratory of the outdoors provides the best method of fostering the positive values of respect and responsibility for our prairies. What needs to be done? We have formed a Society, and have bought land. Our membership is expanding, but we need wider support, more publicity and indications to the government that this project is considered by the public to be worthwhile. So far, we have received only support in principle from the Departments of Environment, Tourism and Renewable Resources, and Education. Chiefly, of course, we need money and have started a fund-raising drive for capital expenses, hoping to get the major donations from companies and granting foundations. What other ways can individuals help? How about looking

\section{Letters}

\section{GYRFALCONS \\ NEAR SALTCOATS, SASKATCHEWAN, 1963-64}

Throughout the winter of 1963-64 I made nearly 20 observations of Gyrfalcons, chiefly along Cutarm Creek south of Saltcoats. All but one or two sightings were of dark-phase birds. In the fall of 1964 I made the following Gyrfalcon observations: November 18 and November 25, dark phase; December 6, light phase; December 26, dark phase. - Bill Horseman, Box 22, Saltcoats, Saskatchewan. through the attic or basement $f c$ equipment that could be useful - $\mathrm{ki}$ chen equipment for the cabins; park: or boots for children who might com inadequately prepared; buildin materials, and farm and foo processing equipment of all type Remember that all donations, whethe used goods or cash, are tax deductibl Or perhaps you'd like to undertake specific project, such as setting up fish farm, weather station, observator for stars, weaving program, fru cellar, ski trails, or a-check-list of th birds of the area. Finally, maybe you enjoy spending some holiday time weekends with us.

To join or help, call or write to:

Prairie Lore and Living Society, 45 Langley St., Regina, Sask.

Don Stewart, R.R. 2, Craven.

(Phone 485-2754)

Jack Mackenzie, 307-2720 College Ave., Regina.

(Phone 523-0192)

\section{ROAD ALLOWANCES}

On Page 54 of the March, 1974 Blue Jay, an article by Hugo Tiessen or Road Allowances was exactly what had often thought about.

These approximately $90-\mathrm{ft}$. wide strips designated as road allowances are not all used for roads and are left idle in many instances, providing windbreaks, shelter for birds. Many are dense with Saskatoons, Chokecherry and wild roses. They provide food for birds and often a slough for water birds - real little wild parks. Needing no money for upkeep, no expensive park wardens, just asking to be left alone to preserve our heritage.

In the past, municipalities have of 